\title{
Zinaida Gippius and Russian Poetry ${ }^{1}$
}

$\mathcal{P}$ age 14 of Temira Pachmuss's book shows a photograph of an exquisitely flower-like young girl in a frilly white frock; on page 5, there is a reproduction of a Léon Bakst watercolor that depicts a sneering young dandy in stylized male attire of the Napoleonic era. Both pictures are portraits of Zinaida Gippius (her German ancestors spelled the name Hippius before they emigrated to Russia in the sixteenth century), Russia's most profound religious poet, a guiding spirit of the Russian Symbolist movement, one of the main initiators of the religious revival among the liberal intelligentsia of the turn of the century, and a spectacular early practitioner of psychological unisex, who rejected the traditional male/ female roles as early as the 1890s. Unpublishable and virtually unknown in the Soviet Union, she is the subject of two highly informative studies that have appeared recently in the West.

In 1889, at the age of twenty, Gippius was married to the rising novelist and critic Dmitry Merezhkovsky. They lived together for the rest of their lives in a fraternal, never-consummated marriage which was an intellectual partnership more than anything else. Although it was Merezhkovsky who eventually attained international fame with his book on Tolstoi and Dostoevsky and with his historical novels (one of them, The Romance of Leonardo da Vinci, has been shown to have served Sigmund Freud as a primary source for his psychoanalysis of Leonardo), all their friends agree that Gippius supplied Merezhkovsky with the stimuli and ideas for everything he wrote. And indeed, in retrospect, there can be no doubt that she was by far the more significant and influential writer of the two. The poems she published in 1893 and 1894 spelled the beginnings of

1 Review of Paradox in the Religious Poetry of Zinaida Gippius, by Olga Matich (Munich: Wilhelm Fink, 1972), and Zinaida Hippius: An Intellectual Profile, by Temira Pachmuss (Carbondale: Southern Illinois University Press, 1971). Originally published as "The Dostoevsky of Russian Poetry" (not SK's choice of title) in Nation, 21 August 1972, 117-19. 
modern Russian poetry. In them she expanded the boundaries of nineteenth-century meters and popularized the accentual verse and assonance rhymes that were later developed and perfected by Aleksandr Blok, Anna Akhmatova, and Osip Mandelstam. At a time when Russian criticism was dominated by utilitarian-minded Positivists who tolerated poetry only if it preached a simplistic moral or contained social criticism, Gippius was one of the first to take up the basic themes of Symbolism (which were to remain central to all her subsequent writings): man's need for religious faith, the problem of achieving freedom in a necessity-bound world, the ambiguities of sexual roles in any love relationship, and the inevitability of death as an ever-present factor in our lives. Andrew Field was not exaggerating when he wrote that the poetry of Gippius "can be nothing less than what Dostoevsky himself would have written had he been a poet." In a very real sense, the position of Gippius in Russian poetry is indeed almost exactly analogous to that of Dostoevsky in the Russian novel. And of course, without her pioneering example neither Blok nor Mayakovsky would have been what they later became.

In most of her poems Gippius spoke of herself in the masculine gender (much more fully expressed in Russian grammar than in English). In her love lyrics, this masculine persona addresses now a female, now a male lover. This ambivalence was also present in her personal life. Her intellectual partnership with Merezhkovsky remained the most important of her relationships, but it left Gippius unsatisfied emotionally. A few incipient affairs with young poets and politicians in the late 1890s all ran aground on her inability and unwillingness to assume the traditional female role. She also had some close emotional involvements with other women and even addressed love lyrics to a few, but these attachments all seem to have been of secondary importance. Believing herself to be a woman physically but a man spiritually and emotionally, Gippius finally came to the conclusion that her ideal soul mate had to be a male homosexual who would be interested in neither a dominant masculine nor a submissive feminine stance. Her choice fell upon Dmitry Filosofov, the spectacularly handsome son of the Russian feminist leader Anna Filosofova. Filosofov was a literary critic, and, at the time, the lover of his cousin

2 Andrew Field, The Complection of Russian Literature: A Cento (New York: Atheneum, 1971), 274. 
Sergei Diaghilev, with whom he edited the pathbreaking journal The World of Art. With Merezhkovsky's willing assistance, Gippius resolutely set out to break up the relationship between Filosofov and Diaghilev, using as her main lever Filosofov's religious and mystical inclinations and interests, which Diaghilev was not able to share. The tug of war between Gippius and Diaghilev over the young critic's affections, which developed over a period of several years and which finally culminated in the victory of Gippius in 1905, had an effect on the entire future of Russian culture that is not generally realized and that had ramifications going far beyond this apparently private emotional tangle. In order to keep Filosofov more securely within their orbit, Gippius and Merezhkovsky initiated the famous encounters between Russian intellectuals and writers on the one hand and the Orthodox clergy on the other at the Religious-Philosophical Society. Russian intellectuals and Russian clergymen had been almost totally estranged since some time in the 1860s, and the resulting rapprochement led to the religious-cultural renascence that helped assert the reputations of such religious philosophers as Nikolai Berdyaev and Lev Shestov, supplied the essential religious strains in the poetry of the early Blok and the late Pasternak, and had an influence that can still be felt in such major works of Soviet literature as Bulgakov's The Master and Margarita, Pasternak's Doctor Zhivago and Solzhenitsyn's August 1914. For his part, Sergei Diaghilev was so crushed by the defection of his lover that he lost all interest in editing the remarkable journal the two of them had founded and decided to shift the center of his interest from painting and literature (with which he had been principally involved in the preceding ten years) to music and ballet. The impact of the ensuing series of concerts and ballet performances which Diaghilev took to Paris (he organized them partly in order to be away from St. Petersburg and to avoid seeing Gippius or Filosofov) on music, ballet, and the visual arts, both in Russia and throughout the world, is too well known to require documentation.

From 1905 until 1920, the group that was known in Russian literary circles as "the Merezhkovskys" consisted of the triumvirate of Gippius, Merezhkovsky, and Filosofov. Like many Russian intellectuals of the time, all three were strongly radicalized by the failure of the abortive Revolution of 1905. They collaborated on the antimonarchist tract The Tsar and the Revolution, which was banned in Russia but was published in France 
and Germany. They also jointly wrote a remarkable play, Poppy Blossoms (Makov tsvet; in her book, Temira Pachmuss translated this title as The Red Poppy, apparently confusing it with Glière's ballet of that name), a picture of the generational conflict occasioned by the 1905 Revolution and aggravated by the polarization of opinion over the desirability and ethics of the Russo-Japanese War. Reading Poppy Blossoms today, one experiences an almost hallucinatory sense of déjà vu: if Vietnam is substituted for Russia's ill-advised attack on Japan, the problems of Russian intellectuals in 1905 as depicted in the play become uncannily similar to those of today's Americans. Even more recognizably, Gippius's play The Green Ring (which is available in English and would make a worthwhile project for some university theater group) depicted the revolt of a group of articulate teenagers against the mercenary and hypocritical values of their parents and elders. In a brilliant production by Vsevolod Meyerhold, The Green Ring was the major event of the 1916 theatrical season; it remains to this day one of the finest genuinely revolutionary and genuinely poetic plays in the Russian language.

The objections of Zinaida Gippius to the tsarist autocracy were that it perpetuated the artificial division of people into social classes and, by supporting an official church and by persecuting religious dissenters and minorities, prevented the individual from seeking his or her own path to God. She saw the aim of the Russian revolutionary movement (which she came to revere) in the establishment of total universal freedom and equality in all aspects of social life; she also believed that the revolution would give people a freedom of choice in their pursuit of religious experience and sexual fulfillment. Lenin's version of the revolution, with its insistence on the primacy of class structure, restriction of sexuality to its most bourgeois forms, and, above all, its total ban on all spiritual life and religious growth, was for Gippius worse than oppression or betrayal of revolutionary ideals: it was sacrilege and deicide. No one among the Russian émigrés denounced the Soviet regime with greater fury and virulence than she, but the relentless bitterness and hatred of her anti-Bolshevik diatribes and poems poison her message and render her jeremiads unpalatable even for those who might sympathize with her reasons.

The loss of Filosofov, who in 1920 left the Merezhkovskys to join a group of revolutionary anarchists based in Poland, was as shattering a blow to Gippius as the October Revolution. In emigration, Gippius pro- 
duced two volumes of literary memoirs, some critical articles, and a slim book of verse in her best metaphysical manner. ${ }^{3}$ Otherwise, the outside world knew her during those years as the wife of the noted writer Merezhkovsky. She outlived him by four years and died in 1945 in Paris, after completing her literary biography of him. ${ }^{4}$

Gippius became an Orwellian unperson in the Soviet Union after about 1925, and for several decades the position of literary historians there was that she had simply never existed. Her name began to reappear in Soviet encyclopedias and references after the 1960s, but she is mentioned only to be denounced as a decadent and a benighted reactionary who dared disagree with Lenin and Gorky. ${ }^{5}$ Because of her historical and artistic importance, it was inevitable that Gippius would be rediscovered by foreign scholars. The book by Olga Matich, originally a UCLA doctoral thesis, was published in Germany (but in the English language) by a Munich publishing house that specializes in important Russian writers and works which are banned in the Soviet Union for nonliterary reasons. Ostensibly a study of a particular aspect of Gippius's poetry, the book is actually a balanced and thoroughly objective outline of this poet's system of thought. The introductory chapter should lay to rest the many spurious legends and invidious myths that are still to be found about Zinaida Gippius in many non-Russian sources. The remainder of the book examines, under the suggestive chapter headings, "God," "Love," "Despair," "Devil," and "Death," the unique personal cosmogony and the powerful religious vision embodied in this astounding woman's poetry. Were it not for the fact that the poetry itself is quoted in the original Russian and without

3 Zinaida Gippius, Zhivye litsa, vols. 1 and 2 (Prague: Plamia, 1925). SK underestimates the sheer number of critical articles and the prose fiction that Gippius published in the 1920s and the 1930s. Three volumes comprising her "unknown prose" of the émigré period, totaling over 1,500 pages, have now been published in St. Petersburg by the publishing house Rostok: Mechty i koshmar (2002); Chto ne bylo i chto bylo (2002); and Arifmetika liubvi (2003). Her final collection of poetry appeared on the eve of World War II: Zinaida Gippius, Siianiia (Paris: Dom knigi, 1938)._Ed.

4 Z. Gippius-Merezhkovskaia, Dmitrii Merezhkovskii (Paris: YMCA-Press, 1951).

5 There has been an explosion of interest around Gippius in post-Soviet Russia. See especially Z. N. Gippius, Stikhotvoreniia; Zhivye litsa, ed. N. A. Bogomolov (Moscow: Khudozhestvennaia literatura, 1991); Z. N. Gippius, Stikhotvoreniia, ed. A. V. Lavrov (St. Petersburg: Novaia biblioteka poeta, 1999); and a nine-volume set of her collected works, Sobranie sochinenii, published in Moscow by Russkaia kniga, between 2001 and 2005 (a supplemental volume followed in 2006)._Ed. 
translation, this book could be recommended as the most thorough and intelligent introduction to the thought and poetry of Zinaida Gippius ever written.

The "Intellectual Profile" by Temira Pachmuss is broader in scope and more ambitious than Professor Matich's study. Based on an enormous amount of research and drawing on a large body of unpublished manuscripts and documents, the volume builds up an impressive case for the importance of the entire Gippius phenomenon for the development of Russian poetry and culture as they exist today. All serious students of Russian literature, who are already indebted to Professor Pachmuss for her recent publications in France and Germany of the diaries of Zinaida Gippius, of her collected poetry, and of her memoirs (the latter two through the good offices of the same German publisher that brought out Olga Matich's book), ${ }^{6}$ should be grateful for the thorough documentation and the great deal of new information on the life and writings of Gippius that the book contains. If the portrait of Zinaida Gippius that ultimately emerges is not entirely satisfactory, it is because the book is handicapped by the author's attitude of excessive adulation toward her subject, paradoxically combined with a lack of genuine affinity for Gippius's views and interests. The sexual ambivalence, so very important in both the poet's life and her poetry, is either lifted to a metaphysical level or coyly swept under the carpet (even the nature of Gippius's attachment to Filosofov, discussed in print by a number of previous commentators, is never made explicit in the book). The interpenetration of the sexual urge and the quest for God, so very basic to the thought of both Gippius and Merezhkovsky, is likewise treated with skittish prudery, The poet's plays, so significant and relevant for today's readers, are dismissed by Professor Pachmuss in a few curt paragraphs, and instead she concentrates her biggest guns on asserting the reputation of Zinaida Gippius as a literary critic.

6 Z. N. Gippius, Stikhotvoreniia i poemy, vol. 1, 1899-1918, and vol. 2, 1918-1945, ed. Temira Pachmuss (Munich: Wilhelm Fink, 1972). See also Temira Pachmuss, Intellect and Ideas in Action: Selected Correspondence of Z. N. Gippius (Munich: Wilhelm Fink, 1972). Professor Pachmuss was also the editor responsible for diaries and memoirs of Gippius which appeared in various émigré periodicals; an abridged version of them in English is to be found in Between Paris and St. Petersburg: Selected Diaries of Zinaida Gippius, ed. Temira Pachmuss (Urbana: University of Illinois Press, 1975)._Ed. 
Now, both before and after the revolution, Gippius indeed published a great deal of criticism under the pen name of Anton Krainy ("Anton the Extreme"). As a critic she was unbelievably narrow-minded and almost totally blind to literary quality as such. She expected her own kind of metaphysical subtlety from all other writers and was simply not interested in any writing that did not in one way or another descend from the Dostoevskian tradition. This parti pris led her to condemn as frivolous and insignificant prose writers of the caliber of Maksim Gorky, Anton Chekhov (who for Gippius was a provincial dullard able to describe only the animal side of human existence), and Vladimir Nabokov ("a writer who has absolutely nothing to say"), and to treat with contempt almost all the important Russian Postsymbolist poets, including such figures as Mayakovsky, Esenin, Pasternak, Anna Akhmatova, and Marina Tsvetaeva. Instead of trying to explain why the very qualities that made Gippius such an original thinker and poet also made her blind as a critic, Temira Pachmuss hastens to agree with all of her subject's foibles and prejudices, quoting with approval such patent absurdities as the assertion that Chekhov held all women in contempt (as supposedly proven by the character of Natasha in Three Sisters). "Hippius deserves recognition as an original and perceptive critic, whose judgment in literary matters has stood the test of time," Professor Pachmuss writes at the end of her detailed chapter on the poet's criticism, but everything she herself cites in the preceding eighty pages belies this sanguine evaluation.

"The religious thought which was typical of the Russian intelligentsia at the turn of the century has no validity today," writes Professor Pachmuss at the beginning of her book, leaving one wondering where she has been for the past ten years and why she bothered to write a book on Zinaida Gippius in the first place. For anyone who is at all aware of the recent trends in modern sensibility in the Western countries, Temira Pachmuss's own fact-filled book and Olga Matich's perceptive study should offer ample proof that the religious thought of Zinaida Gippius and of her contemporaries is remarkably valid and fascinating today and that this poet's tortuous search for freedom from sexual stereotypes can be understood far better now than it was in earlier decades. The English translations of Gippius's poems offered in Professor Pachmuss's book are regrettably pedestrian in quality and are frequently inexact. Should some talented translator come up with better renditions as a result of these two 
new books on Gippius, there would very likely be an eager and receptive audience in the West for the poems, plays, diaries, and memoirs of this unfairly and undeservedly forgotten writer who changed the course of poetry in her own country and who foreshadowed so many of our presentday insights and attitudes.

With this review, SK deeply offended Temira Pachmuss, who had long devoted much of her scholarly research to Zinaida Gippius and, as a result, had also inherited the papers of Gippius left to Vladimir Zlobin, the erstwhile factotum of the Merezhkovskys. She bided her time, but when SK published his edition of an English translation of Zlobin's memoirs, with a reiteration and expansion of his criticism of Pachmuss's views and allegations of censorship, she published an impassioned defense of her own work and a rebuttal of SK's trust in the veracity of Zlobin's memoirs. 'To some readers, SK's tracing of cause and effect in the interpersonal relationships and careers of the Merezhkovskys, Filosofov, and Diaghilev may seem overblown.

This essay also provoked a standard denunciation of SK in the Soviet press. In a polemical article published in the official newspaper of the Union of Writers, he was taken to task for denigrating Dostoevsky's alleged "SocialistRealist" credentials and, on the other hand, championing a vociferously anti-Bolshevik representative of the emigration. ${ }^{8}$ The lengthy diatribe, with its several quotations from SK's writings, however, had the result of airing the selective and blinkered treatment of Dostoevsky in party-line literary criticism in the Soviet Union and of introducing Zinaida Gippius-together with her political and religious heterodoxy and her unconventional views of sexuality-to readers who never knew she existed. (Indeed, this may well have been the journalist's not-so-hidden agenda.)

7 Temira Pachmuss, review of A Difficult Soul: Zinaida Gippius, by Vladimir Zlobin, ed., annotated, and with an introduction by Simon Karlinsky (Berkeley: University of California Press, 1980), in Slavic Review 40, no. 3 (Fall 1981): 505-6. SK's response and Professor Pachmuss's reply appeared in Slavic Review 41, no. 1 (Spring 1982): 195-96.

8 A. Ponomarev, "Grimiruia pod velikikh: Neliteraturovedcheskie operatsii amerikanskogo literaturoveda," Literaturnaia gazeta, 5 November 1972. 